\title{
Charcoal Production in a Cocoa-Farming Area: Plant Species Used and Their Sources
}

\author{
Philomena Kumapley and Francis Azumah \\ Department of Silviculture and Forest Management, Faculty of Renewable Natural Resources, Kwame Nkrumah University of \\ Science and Technology, Kumasi, Ghana
}

\begin{abstract}
The authors investigated the plant species used for charcoal production and their sources and the willingness of the producers to plant charcoal-making species. Furthermore, the authors indirectly determined the involvement of farmers in charcoal production in Atwima Mponua District of Ghana. A total of 120 producers were interviewed and simple ranking was used for the analysis. Twenty-three plant species were used with the first, second, third and fourth which were Celtis mildbraedii, Cylicodiscus gabunensis, Margaritoria discoides and Amphimas pterocarpoides respectively. However, the Amphimas pterocarpoides was not among the traditional charcoal-producing species. The wood used came from seven different sources. None of the charcoal producers had a plantation of charcoal-producing species. Only $13 \%$ of the producers were willing to plant, $87 \%$ of them who were not willing to plant indicated that they would leave charcoal production if the resource got finished. The 120 charcoal producers were made up roughly of $56 \%$ males, and $44 \%$ females and in which $69.2 \%$ of them were farmers.
\end{abstract}

Key words: Theobroma cacao, charcoal-making species, farmers, willingness to plant, other income-generating activities, crops grown.

\section{Introduction}

Charcoal is produced by burning biomass, especially, wood in a restricted supply of air [1]. Crucial as it is for cooking, charcoal comes at a cost: the wood burned to create it comes from forests, generating substantial carbon emissions [2]. As with all systems, forests do not exist in isolation. They affect and are affected by some of the world's greatest challenges, poverty, climate change, food security, biodiversity and are interconnected with surrounding land use such as farming and settlements [3]. Climate has an important influence on the nature of the natural vegetation, the characteristics of the soils, the crops that can be grown and the type of farming that can be practiced in any region [4]. In Ghana, zonal differences in cropping patterns are clearly recognizable. In the forest zones, food crops are cultivated alongside cocoa, the predominant cash

Corresponding author: Philomena Kumapley, Ph.D., research field: charcoal production. E-mail: perpkumapley@yahoo.com. crop in the country. This crop also has a large global market [5]. According to Baxter, J. [6], farmers have struggled to cope with fluctuating cocoa prices in the wake of economic liberalization policies in the producing countries that had helped to stabilize cocoa prices and buffer the farmers from volatile global markets. Fortunately, new research is pointing to the possibility of smallholder cocoa farmers increasing their income through crop diversification. Farms, like other businesses, make money or income (sometimes) [7]. Charcoal production offers farmers an opportunity to diversify their livelihood strategies. Additionally, it is sometimes described as a business in which quick money can be made [8]. However, since the resource base for charcoal production is declining [9] and charcoal production can be a primary or a secondary activity [1]. The objectives of this study, therefore, were to determine (1) the plant species used for charcoal production and their sources; (2) the willingness of the producers to plant charcoal-making species and (3) indirectly determine 
the involvement of farmers in charcoal production in the area.

\section{Methodology}

The study took place in Atwima Mponua District of the Ashanti Region of Ghana (Figs. 1 and 2). The data collection took place in 12 localities including Nyinahin, Adupri and Sreso Timpon. A total of 120 charcoal producers were interviewed through the use of questionnaires. In order to get answers for the third objective, the charcoal producers were asked among other things to specify the types of other income-generating activities they had. In addition, those who were farmers were requested to mention the crop or crops they grew. Simple ranking was used for the analysis with the most frequently mentioned category being ranked first.

\section{Results}

The charcoal producers included both males and females with the males being slightly in the majority as shown in Table 1.

The plant species used for the charcoal production were 23 in all. The details of the species and their individual ranks are in Table 2.

The sources of the wood used for the charcoal production were as equally important as the species themselves. The bush or the surrounding fallow areas ranked as the first source where over $91 \%$ of the producers obtained their wood (Table 3). Farms

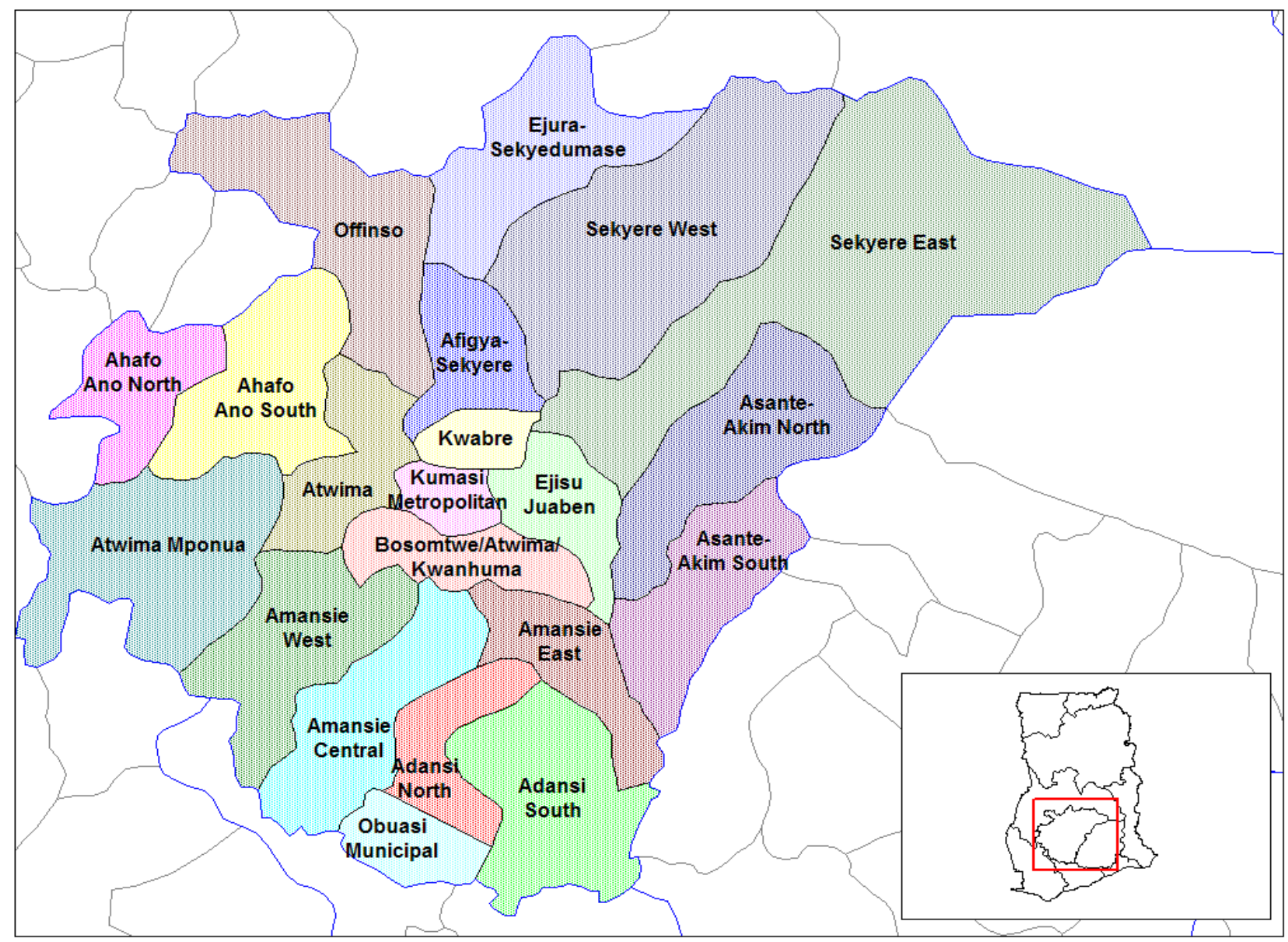

Fig. 1 Map of Ashanti region [17]. 
Fig. 2 Map of Atwima Mponua [17].

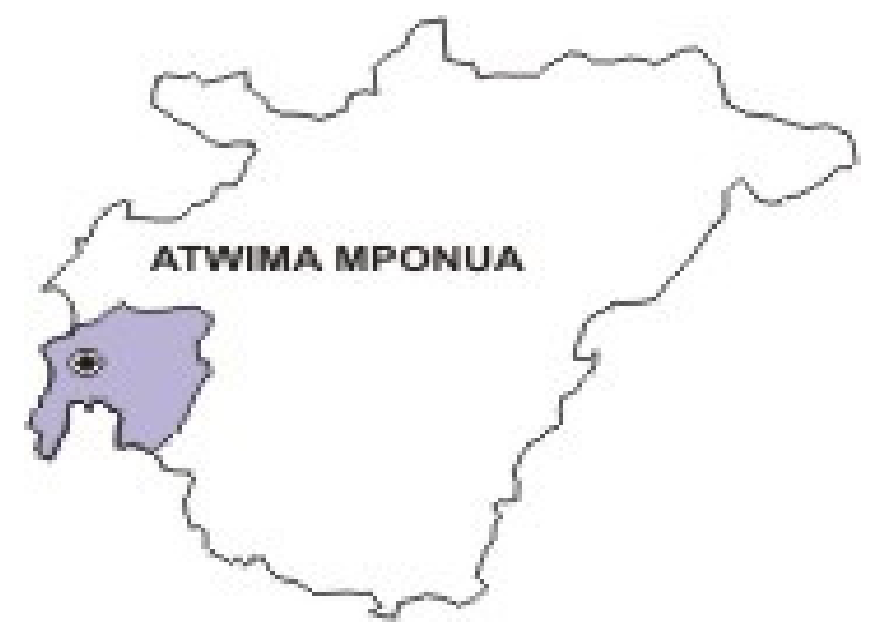

Table 1 Gender of charcoal producers interviewed.

\begin{tabular}{llll}
\hline $\begin{array}{l}\text { Number of localities from which people were } \\
\text { interviewed in the District }\end{array}$ & Number of charcoal producers interviewed & Males & Females \\
\hline 12 & 120 & 67 & 53 \\
& & $55.8 \%$ & $44.2 \%$ \\
\hline
\end{tabular}

Table 2 Plant species used for producing charcoal.

\begin{tabular}{|c|c|c|}
\hline Species & Percentage & Rank \\
\hline Celtis mildraedii & 20.1 & $1 \mathrm{st}$ \\
\hline Cylicodiscus gabunensis & 15.4 & $2 \mathrm{nd}$ \\
\hline Margaritaria discoides & 12.2 & $3 \mathrm{rd}$ \\
\hline Amphimas pterocarpoides & 11.8 & 4 th \\
\hline Albizia zygia & 10.7 & 5 th \\
\hline Piptadeniastrum africanum & 10.1 & 6 th \\
\hline Milicia excels & 5.3 & 7 th \\
\hline Blighia unijugata & 2.1 & 8 th \\
\hline Nesogordonia papaverifera & 1.9 & 9 th \\
\hline Mangifera indica & 1.7 & 10 th \\
\hline Memycelon afzelii & 1.5 & 11 th \\
\hline Ficus capensis & 1.3 & 12 th \\
\hline Pseudospondias microcarpa & 1.1 & 13 th \\
\hline Khaya senegalensis & 1.1 & 13 th \\
\hline Cola gigantean & 0.6 & 15 th \\
\hline Entandrophragma cylindricum & 0.6 & 15 th \\
\hline Terminalia ivorensis & 0.4 & 17 th \\
\hline Tectona grandis & 0.4 & 17 th \\
\hline Tieghemella heckelii & 0.2 & 20 th \\
\hline Ficus sp. & 0.2 & 20 th \\
\hline Albizia ferruginea & 0.2 & 20 th \\
\hline Senna siamea & 0.2 & 20 th \\
\hline Tetrapleura tetraptera & 0.2 & 20 th \\
\hline
\end{tabular}


Table 3 Sources of wood used for charcoal production.

\begin{tabular}{llll}
\hline Source & Number of respondents who chose "yes" & Percentage & Rank \\
\hline Cut from the bush/surrounding fallow areas. & 110 & 91.7 & $1 \mathrm{st}$ \\
$\begin{array}{l}\text { Cut from other people's farm with their } \\
\text { permission for a fee/payment. }\end{array}$ & 107 & 89.2 & $2 \mathrm{nd}$ \\
Cut from own farm & 96 & 80 & $3 \mathrm{rd}$ \\
Buy the wood & 74 & 61.7 & 4 th \\
Cut from the forest for free & 53 & 44.2 & 5 th \\
Cut from the forest for a fee & 14 & 11.7 & 6 th \\
Cut from other people's farm with their & 3 & 2.5 & 7 th \\
permission for free/without paying. & 0 & 0 & -- \\
Have own plantation of charcoal making species & 0 & 0 &
\end{tabular}

followed as the second and the third in importance; these farms being other people's farms and farms of the charcoal producers themselves respectively.

For every option there were answers for "Yes" and "No". All the producers did not use wood from all the sources. For some sources the answers added to $100 \%$. For others they did not.

None of the charcoal producers had a plantation of charcoal-making species.

Not all plant species can be used to produce good charcoal. Due to this fact, charcoal producers selectively harvest species that have the required characteristics. The second objective, therefore, dealt with the willingness of the producers to plant charcoal-producing species.

Almost $87 \%$ of them were not willing to plant (Table 4) and almost this percentage was prepared to stop charcoal production if the wood got finished (Table 5).

The study also tried to find out the involvement of farmers in charcoal production in the area.

Among the sample interviewed $69.2 \%$ of them were farmers (Table 6). These farmers grew a total of 15 different crops including cocoa, the crops and their ranks are shown in Table 7.

The crops could be put into two groups: the cocoa-crop combination (Table 8) and the non-cocoa crop combination (Table 9).

Table 4 Willingness of the charcoal producers to plant charcoal producing species.

\begin{tabular}{llll}
\hline & No & Yes & Total \\
\hline \multirow{2}{*}{ Willing to plant } & Number: 104 & Number: 16 & 120 \\
& Percentage: $86.7 \%$ & Percentage: $13.3 \%$ & 100 \\
\hline Table 5 & The future plan of the charcoal producers. & & \\
\hline & Yes & No & Total \\
\hline \multirow{2}{*}{ Would leave charcoal production } & Number: 104 & Number: 15 & 119 \\
& Percentage: $86.7 \%$ & Percentage: $12.5 \%$ & 99.2 \\
\hline
\end{tabular}

Table 6 Other income-generating activities of the charcoal producers.

\begin{tabular}{lll}
\hline Category & Numbers of respondents & Percentage \\
\hline Farmers & 83 & 69.2 \\
Unemployed & 10 & 8.3 \\
Various skilled workers & 9 & 7.5 \\
Traders & 8 & 6.7 \\
Others & 10 & 8.3 \\
Total & 120 & 100 \\
\hline
\end{tabular}


Table 7 Crops grown by the farmers.

\begin{tabular}{lll}
\hline Common names & Percentage of farmers growing crop & Rank \\
\hline Plantain & 23.4 & 1 st \\
Yam & 21.3 & 2 nd \\
Cocoa & 15.7 & 3 rd \\
Cassava & 11.9 & 4 th \\
Maize & 10.5 & 5 th \\
Tomatoes & 3.5 & 6 th \\
Onion & 3.2 & 7 th \\
Garden eggs & 2.8 & 8 th \\
Cocoyam & 2.5 & 9 th \\
Okro & 1.4 & 10 th \\
Pepper & 1.4 & 10 th \\
Oil palm & 1.1 & 12 th \\
Orange & 1 & 13 th \\
Pineapple & 1 & 13 th \\
Rice & 1 & 13 th \\
\hline
\end{tabular}

\section{Discussion}

The 23 species used for charcoal production in Atwima Mponua included two species that were not among the over 70 species mentioned by the authors $[10,11]$ for charcoal production in Ghana. These were Amphimas pterocarpoides and Mangifera indica. Using non-traditional species for charcoal production is one indicator of deteriorating resource situation. Mango, Mangifera indica L. is one of the most celebrated tropical fruits [12]. In Tanzania, mango trees are one category of farm land trees used for charcoal production [13]. Trees outside forests and woodlands, including among others on-farm trees have a major role to play as sources of fruits and their importance should not be underestimated [14]. Concerning the declared intention of a section of the charcoal producers to leave charcoal production when the resource got exhausted, it is questionable how this would play out. This is because that the farmer/charcoal producers are engaged in charcoal production as a source of additional income now. The crops shown in Tables 7-9 need different periods for their growth, some being annuals others perennials. While cocoa is a tree crop, others are short-cycle annual crops.

For example, maize [15] requires different financing systems. Climate change is one of the challenges facing the world today. According to the intergovernmental Panel on Climate Change Working Group II 2014 [16] based on many studies covering a wide range of regions and crops, negative impacts of climate change on crop yields have been more common than positive impacts. Consequently, one could say that requiring additional source of income and being on-farm or off-farm may be more urgent in the future than putting more trees now. Because their forest, woodland or on farm trees at risk as sources of wood for charcoal production.

\section{Conclusions}

Over twenty species recorded as used for charcoal production in this study also have other competing uses. The two non-traditional species among the list confirmed a deteriorating resource situation for charcoal production. Even though just expressing the willingness to plant might not translate into planting charcoal-producing species, it could be considered as an indication of the charcoal producers' willingness to participate in the restoration of the landscape and its biodiversity. Unfortunately, the percentage prepared to do this was woefully low. 
Table 8 Cocoa-crop combinations grown by the farmers/charcoal producers.

\begin{tabular}{|c|c|c|c|c|c|c|c|c|c|c|c|c|c|c|c|c|}
\hline & \multicolumn{16}{|c|}{ Crops combinations } \\
\hline & $\begin{array}{l}\text { Pine- } \\
\text { apple }\end{array}$ & $\begin{array}{l}\text { Cass- } \\
\text { ava }\end{array}$ & $\begin{array}{l}\text { Co- } \\
\text { coa }\end{array}$ & $\begin{array}{l}\text { Plan- } \\
\text { tain }\end{array}$ & Yam & Maize & $\begin{array}{l}\text { Coco- } \\
\text { yam }\end{array}$ & $\begin{array}{l}\text { Gard- } \\
\text { en eggs }\end{array}$ & $\begin{array}{l}\text { Ok- } \\
\text { ro }\end{array}$ & $\begin{array}{l}\text { On- } \\
\text { ion }\end{array}$ & $\begin{array}{l}\text { Pep- } \\
\text { per }\end{array}$ & $\begin{array}{l}\text { Tom- } \\
\text { atoes }\end{array}$ & $\begin{array}{l}\text { Oil } \\
\text { Palm } \\
\end{array}$ & Rice & $\begin{array}{l}\text { Frequ- } \\
\text { ency }\end{array}$ & Rank \\
\hline 1 & & & $\sqrt{ }$ & $\sqrt{ }$ & $\sqrt{ }$ & $\sqrt{ }$ & & & & & & & & & 11 & $1 \mathrm{st}$ \\
\hline 2 & & $\sqrt{ }$ & $\sqrt{ }$ & $\sqrt{ }$ & $\sqrt{ }$ & & & & & & & & & & 6 & 2 nd \\
\hline 3 & & & $\sqrt{ }$ & $\sqrt{ }$ & $\sqrt{ }$ & & $\sqrt{ }$ & & & & & & & & 3 & $3 \mathrm{rd}$ \\
\hline 4 & & $\sqrt{ }$ & $\sqrt{ }$ & & $\sqrt{ }$ & & & & & & & & & & 3 & $3 \mathrm{rd}$ \\
\hline 5 & & $\sqrt{ }$ & $\sqrt{ }$ & $\sqrt{ }$ & & & & & & & & & & & 3 & $3 \mathrm{rd}$ \\
\hline 6 & & & $\sqrt{ }$ & $\sqrt{ }$ & $\sqrt{ }$ & & & $\sqrt{ }$ & & $\sqrt{ }$ & $\sqrt{ }$ & $\sqrt{ }$ & & & 1 & 6 th \\
\hline 7 & & & $\sqrt{ }$ & & & & & & & & & & $\sqrt{ }$ & & 1 & 6 th \\
\hline 8 & & & $\sqrt{ }$ & $\sqrt{ }$ & & & & & & & & & & & 1 & 6 th \\
\hline 9 & & & $\sqrt{ }$ & & $\sqrt{ }$ & & & & & & & & & & 1 & 6 th \\
\hline 10 & & & $\sqrt{ }$ & $\sqrt{ }$ & & & $\sqrt{ }$ & & & & & & & & 1 & 6 th \\
\hline 11 & & & $\sqrt{ }$ & & & $\sqrt{ }$ & & & & & & & & $\sqrt{ }$ & 1 & 6 th \\
\hline 12 & & & $\sqrt{ }$ & $\sqrt{ }$ & $\sqrt{ }$ & & & & & $\sqrt{ }$ & & & & & 1 & 6 th \\
\hline 13 & & & $\sqrt{ }$ & & $\sqrt{ }$ & $\sqrt{ }$ & & $\sqrt{ }$ & $\sqrt{ }$ & $\sqrt{ }$ & $\sqrt{ }$ & $\sqrt{ }$ & & & 1 & 6 th \\
\hline 14 & & & $\sqrt{ }$ & $\sqrt{ }$ & $\sqrt{ }$ & & & & & & & & $\sqrt{ }$ & & 1 & 6 th \\
\hline 15 & & & $\sqrt{ }$ & $\sqrt{ }$ & $\sqrt{ }$ & & & & & & & $\sqrt{ }$ & & & 1 & 6 th \\
\hline 16 & & & $\sqrt{ }$ & & & & & $\sqrt{ }$ & & & & $\sqrt{ }$ & & & 1 & 6 th \\
\hline 17 & & $\sqrt{ }$ & $\sqrt{ }$ & $\sqrt{ }$ & & $\sqrt{ }$ & & & & & & & & & 1 & 6 th \\
\hline 18 & $\sqrt{ }$ & $\sqrt{ }$ & $\sqrt{ }$ & & & & & & & & & & & & 1 & 6 th \\
\hline 19 & & & $\sqrt{ }$ & $\sqrt{ }$ & $\sqrt{ }$ & & & & & & & & & & 1 & 6 th \\
\hline
\end{tabular}


Table 9 Non-Cocoa crop combinations grown by the farmers/charcoal producers.

\begin{tabular}{|c|c|c|c|c|c|c|c|c|c|c|c|c|c|c|}
\hline & \multicolumn{14}{|c|}{ Crops combinations } \\
\hline & Cassava & Maize & Plantain & Yam & Orange & $\begin{array}{l}\text { Garden } \\
\text { eggs }\end{array}$ & Cocoyam & Onion & Tomatoes & Pepper & Okro & Oil palm & $\begin{array}{l}\text { Frequ- } \\
\text { ency }\end{array}$ & Rank \\
\hline 1 & $\sqrt{ }$ & $\sqrt{ }$ & $\sqrt{ }$ & $\sqrt{ }$ & & & & & & & & & 7 & $1 \mathrm{st}$ \\
\hline 2 & & $\sqrt{ }$ & $\sqrt{ }$ & $\sqrt{ }$ & & & & & & & & & 6 & 2 nd \\
\hline 3 & $\sqrt{ }$ & $\sqrt{ }$ & $\sqrt{ }$ & & & & & & & & & & 6 & 2 nd \\
\hline 4 & $\sqrt{ }$ & & $\sqrt{ }$ & & & & & & & & & & 3 & 4 th \\
\hline 5 & $\sqrt{ }$ & & & & & $\sqrt{ }$ & & $\sqrt{ }$ & $\sqrt{ }$ & & & & 2 & 5 th \\
\hline 6 & $\sqrt{ }$ & & $\sqrt{ }$ & $\sqrt{ }$ & & & & & & & & & 1 & 6 th \\
\hline 7 & $\sqrt{ }$ & $\sqrt{ }$ & & & & & $\sqrt{ }$ & & $\sqrt{ }$ & & & & 1 & 6 th \\
\hline 8 & $\sqrt{ }$ & & $\sqrt{ }$ & $\sqrt{ }$ & & & & $\sqrt{ }$ & & & & & 1 & 6 th \\
\hline 9 & & & & & & & & $\sqrt{ }$ & $\sqrt{ }$ & & $\sqrt{ }$ & & 1 & 6 th \\
\hline 10 & & & & & & $\sqrt{ }$ & & & $\sqrt{ }$ & $\sqrt{ }$ & $\sqrt{ }$ & & 1 & 6 th \\
\hline 11 & $\sqrt{ }$ & & $\sqrt{ }$ & & $\sqrt{ }$ & & & & & & & & 1 & 6 th \\
\hline 12 & & $\sqrt{ }$ & $\sqrt{ }$ & $\sqrt{ }$ & & & $\sqrt{ }$ & & & & & & 1 & 6 th \\
\hline 13 & & & & & & $\sqrt{ }$ & & $\sqrt{ }$ & $\sqrt{ }$ & $\sqrt{ }$ & $\sqrt{ }$ & $\sqrt{ }$ & 1 & 6 th \\
\hline 14 & & & $\sqrt{ }$ & $\sqrt{ }$ & & & $\sqrt{ }$ & & & & & & 1 & 6 th \\
\hline
\end{tabular}




\section{References}

[1] Rosillo-Calle, F., Groot, P., and Hemstock, S. L. 2007. "Assessment Methods for Woody Biomass Supply." In The Biomass Assessment Handbook: Bioenergy for a Sustainable Environment, edited by Rosillo-Calle, F., Groot, P., Hemstock, S. L., and Woods, J. London-Sterling VA: Earthscan.

[2] McCall, C. 2015. "In 'Charcoal Landscape', Data on Deforestation, Emissions Hidden in the Ashes." Forest News. Accessed February 4, 2015. http://blog.cifor.org /26226/zambia-charcoal-deforestation-carbon-emissions-r edd? ga $=1.15$.

[3] CIFOR (Center for International Forestry Research). 2015. "Sustainable Landscapes." Accessed January 17, 2015. http://www.cifor.org/sustainable-landscapes.

[4] Webster, C. C., and Wilson, P. N. 1980. Agriculture in the Tropics. Second Edition. London: Longman Group Limited.

[5] Ngeleza, G. K., Owusua, R., Jimah, K., and Kolavalli, S. 2011. "Cropping Practices and Labor Requirements in Field Operations for Major Crops in Ghana. What Needs to Be Mechanized?" IFPRI Discussion Paper 01074. Accessed December 27, 2014. http://www.ifpri.org/ publication/cropping-practices-and-labour-requirements-f ield-operati.

[6] Baxter, J. 2014. "Crop Diversity Can Sweeten the Deal for African Cocoa Farmers." Forest News. Accessed December 30 , 2014. http://blog.cifor.org/23652/crop-diversity-can-sweeten-th e-deal-for-African-cocoa-farmers.

[7] Rich, Schell, J. D. 2014. "How to Navigate the Tricky World of Farm Taxes." Accessed December 30, 2014. http://www.hobbyfarms.com/farm-marketing-and-manag ement/farm-income-taxes-14991.

[8] Ndjoze, J. 2011. "Charcoal: Still a Multimillion Dollar
Industry." The Villager. Accessed December 30, 2014. http://www.thevillager.com.na/articles/430/Charcoal...Stil 1-a-multimillion-dollar-industry.

[9] Van, Der, Plas, R. 1995. "Energy Issues. Burning Charcoal Issues." The World Bank Group. FDP Energy. Accessed June 26, 2015. http//www-wds.worldbank. org/servlet/WDSContentserver/WDSP/IB/1999/08/15/00 000926.

[10] Irvine, F. R. 1961. Woody Plants of Ghana. London: Oxford University Press.

[11] Abbiw, D. K. 1990. Useful Plants of Ghana. Kew: Intermediate Technology Publications.

[12] Morton, J. 1987. "Mango. In Fruits of Warm Climates." Accessed March 5, 2015. http://www.hort.purdue. edu/newcrop/morton/mango_ars.html.

[13] Malimbwi, R. E., and Zahabu, E. M. 2008. "Woodlands and the Charcoal Trade: The Case of Dar Es Salam City." Working Papers of the Finish Forest Research Institute 98: 93-114.

[14] Rosillo-Calle, F., Groot, P., and Hemstock, S. L. 2007. "General Introduction to the Basis of Biomass Assessment Methodology." In The Biomass Assessment Handbook: Bioenergy for a Sustainable Environment, edited by Rosillo-Calle, F., Groot, P., Hemstock, S. L., and Woods, J. London-Sterling VA: Earthscan.

[15] Jagoret, P., Michel-Dounias, I., Snoeck, D., Ngnogue, H. T., and Malezieux, E. 2012. "Afforestation of Savannah with Cocoa Agroforestry Systems: A Small-farmer Innovation in Central Cameroon." Agroforest Syst. 86: 493-504.

[16] IPCC (Intergovernmental Panel on Climate Change) Working Group II. 2014. "Climate Change 2014: Impacts, Adaptation and Vulnerability.” Accessed July 1, 2014. http://www.ipcc.ch/report/ar5/wg2/.

[17] Ghana Districts. 2015. Accessed April, 2014. http://ghanadistrits.com/distri. 